Original Article

\title{
Microbial source tracking and antimicrobial resistance in one river system of a rural community in Bahia, Brazil
}

\author{
Rastreamento de fontes microbianas e resistência antimicrobiana em um sistema \\ fluvial de uma comunidade rural da Bahia, Brasil
}

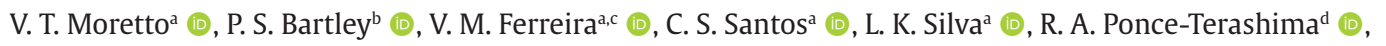
R. E. Blanton ${ }^{\mathrm{b}}$ (D), M. G. Reis ${ }^{\mathrm{a}, \mathrm{c}}$ (1) and L. M. Barbosa ${ }^{\mathrm{a}, \mathrm{c}^{*}}$ (1)

aFundação Oswaldo Cruz - FIOCRUZ, Centro de Pesquisas Gonçalo Moniz - CPqGM, Salvador, BA, Brasil

${ }^{b}$ Case Western Reserve University - CWRU, Center for Global Health and Diseases, Cleveland, OH, US

'Escola Bahiana de Medicina e Saúde Pública - EBMSP, Salvador, BA, Brasil

dMercer University School of Medicine, Division of Infectious Diseases, Macon, GA, USA

\begin{abstract}
Use of antibiotics inevitably leads to antimicrobial resistance. Selection for resistance occurs primarily within the gut of humans and animals as well as in the environment through natural resistance and residual antibiotics in streams and soil. We evaluated antimicrobial resistance in Gram negative bacteria from a river system in a rural community in Bahia, Brazil. Water was collected from the Jiquiriçá and Brejões rivers and the piped water supply. Additionally, stools were collected from a random sample of residents, cows, pigs and horses near the river. The samples were screened for bacteria resistant to ciprofloxacin, cefotaxime, and meropenem and identified biochemically at the genus and species levels. Microbial source tracking demonstrated that ruminant and human fecal contamination increased as the rivers neared the village center and decreased after the last residence. Antibiotic bacteria were identified from all samples $(n=32)$. No bacteria were resistant to carbapenems, but the majority of the enterobacteria were resistant to ciprofloxacin, even though this class of antibiotics is not commonly used in food animals in this region. Considering these facts, together with the pattern of human fecal contamination, a human source was considered most likely for these resistant isolates.
\end{abstract}

Keywords: fecal contamination, Enterobacteriaceae, livestock, sanitation.

\begin{abstract}
Resumo
O uso de antibióticos inevitavelmente leva à resistência antimicrobiana. A seleção para resistência antimicrobiana ocorre principalmente no intestino de seres humanos e animais, bem como no meio ambiente, através da resistência natural e resíduos de antibióticos nos esgotos e no solo. Avaliamos a resistência antimicrobiana em bactérias Gram-negativas de um sistema fluvial em uma comunidade rural da Bahia, Brasil. A água foi coletada nos rios Jiquiriçá e Brejões e no abastecimento de água encanada. Além disso, foram coletadas amostras randomizadas de fezes de moradores, vacas, porcos e cavalos próximos ao rio. As amostras foram triadas para bactérias resistentes à ciprofloxacina, cefotaxima e meropenem e identificadas bioquimicamente nos níveis de gênero e espécie. 0 rastreamento de fontes microbianas demonstrou que a contaminação fecal de ruminantes e humanos aumentou à medida que os rios se aproximavam do centro da vila e diminuía após a última residência. Bactérias resistentes a antibióticos foram identificadas em todas as amostras $(n=32)$. Nenhuma bactéria demonstrou ser resistente aos carbapenêmicos testados, contudo, foi encontrado enterobactérias resistentes à ciprofloxacina, ainda que essa classe de antibióticos não seja comumente usada na medicina veterinária dos animais dessa região. Considerando esses fatos, juntamente com o padrão de contaminação fecal avaliado, a fonte de contaminação humana foi considerada a mais provável na interação desses isolados resistentes.
\end{abstract}

Palavras-chave: contaminação fecal, Enterobacteriaceae, gado, saneamento.

\section{Introduction}

Bacterial infection is a major cause of disease in and out of hospitals, and resistance is growing due to increasing use of antibiotics in humans and domestic animals (Bonelli et al., 2014). There are community and environmental components to antimicrobial resistance that may be equal to or more important than that generated by use and overuse in hospital settings (Gallini et al., 2010; Meirelles-Pereira et al., 2002). Novel antimicrobial

*e-mail: luciobarbosa@bahiana.edu.br

Received: December 17, 2019 - Accepted: July 2, 2020 
resistant bacteria disproportionately originate in lowerincome countries, but eventually extend outside the region where they arose (Baker, 2015). The mere use of antibiotics, however, does not align perfectly with the prevalence of resistance. While the US and Europe have higher levels of antibiotic use than Brazil (Laxminarayan et al., 2013), the problem of resistance is similar (Marra et al., 2011). This paradox may in part be explained by poor sanitation contributing to fecal bacterial mingling (Bartley et al., 2019) and transmission of resistance via conjugative plasmids (Kumarasamy et al., 2010) or the presence of sublethal concentrations of antibiotics (Berglund, 2015). Cell-cell contact between bacteria, such as occurs in polluted waters, is required for R-plasmid transmission. Gene transfers that occur across species and in hospitals may not even be the major location for development and transfer of resistance (Berglund, 2015; Vaidya, 2011). In developing countries, $80 \%$ of antimicrobials are consumed outside of the hospital setting (Chang et al., 2015).

Human fecal contamination is an additional factor for the distribution of antibiotic resistance in low or middle-income countries where sanitation is inadequate (Newton et al., 2015; Liang et al., 2020). In rural areas, human bacteria mix with bacteria from our commercial domestic animals (Berglund, 2015). Antibiotic administration is important in both populations and both can be a source of antibiotic resistance. Horizontal gene exchanges among bacteria are common even between species (Brown-Jaque et al., 2015). One of the most efficient forms of exchange is by means of conjugative plasmids that require cell-cell contact for transmission (Berglund, 2015).
In a rural community in Brazil, we compared a spectrum of antibiotic resistance for Enterobacteriaceae from the principal human water contact points along two main rivers, the piped water supply and fecal samples from the human and domestic animal populations. In order to further gauge the contribution of human and animal sources of contamination, the water samples were also assayed for human or ruminant fecal concentration and common antibiotic resistance genes.

\section{Material and Methods}

\subsection{Study area}

The rural community of Jenipapo (13²'04"S, $39^{\circ} 42^{\prime} 58^{\prime} \mathrm{W}$ ) is administrated by Ubaíra county, located $270 \mathrm{~km}$ southwest of Salvador, the capital of Bahia. Jenipapo does not have an estimated human development index (HDI). However, Ubaíra has an HDI of 0.582, which is slightly below the average for the state of Bahia (0.660). According to the National Agency of Waters (Agência Nacional das Águas), 70\% of Ubaíra's population have basic sanitation coverage, while the state of Bahia has only 50\% (ANA, 2017). The community (population 619 in 2015) is divided north and south by the Jiquiriçá River and bordered on the west by the Brejões River at the point where it flows into the Jiquiriçá (see Figure 1). The main livelihood is small-scale cultivation of bananas, cassava, cacao and large and small livestock. Along both rivers, $89 \%$ of the area is pastureland and 3\% used for agriculture (Fernandes et al., 2010). In a previous study we described in this community that

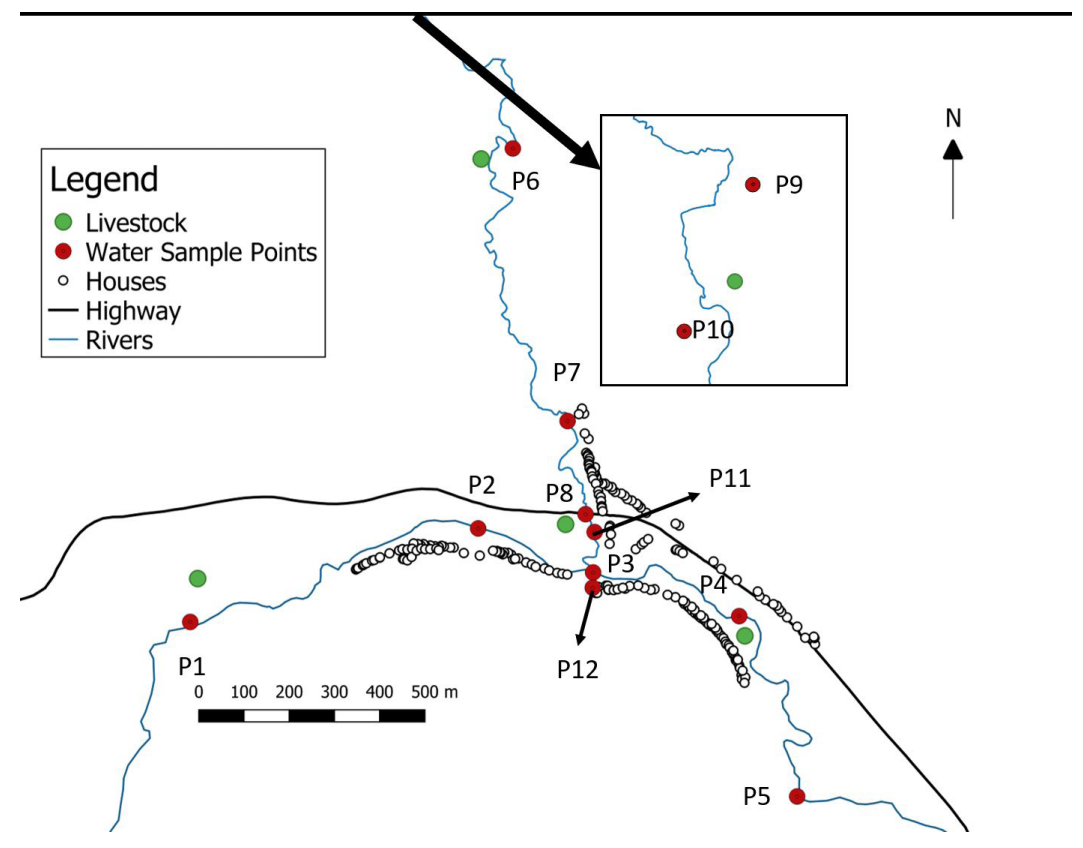

Figure 1. Study area, rivers and water collection sites. The collection points on the Jiquiriçá River are P1-5; collection points on the Brejões P6-8. P3 is at the junction of the 2 rivers, and P9 and P10 are from the water treatment plant and an outside faucet, respectively. Left inset - Location of Bahia state, Salvador and Jenipapo within Brazil based on Wikimedia Commons (2011). Right inset - relationship of P12 and P13 to Jenipapo. These 2 points represent the source of piped water for the community and the furthest point upstream for collection on the Brejões River, respectively. Inset modified from Wikimedia Commons (2011). 
while $>90 \%$ of homes have a flush toilet, less than $50 \%$ report that their toilets discharge to septic tanks and the remainder to the rivers (Barbosa et al., 2013). To our knowledge, there are no official records of antibiotic use for livestock or humans in this village, however this is a common scenario in Brazilian's rural communities. Drinking water is supplied from a small reservoir $8 \mathrm{~km}$ north of the village on the Brejões watershed (see Figure 1, Point 10) and piped to a water treatment plant in the village (see Figure 1, Point 11), where it is filtered and chlorinated. We also collected drinking water from a public source (Point 12) that is located after the water treatment plant. All water collection points and households were georeferenced using a Nomad GPS unit Model 65220-11 (Trimble Navigation Ltd., Sunnyvale, CA).

\subsection{Water collection}

Water samples were collected in July 2015 at 10 sites along the Jiquiriçá and Brejões Rivers and two sites from the community's piped water system (Figure 1). At each site, water was collected in midstream between $8 \mathrm{AM}$ and $12 \mathrm{PM}$ in clean $500 \mathrm{~mL}$ bottles for filtration and in sterile $50 \mathrm{~mL}$ conical tubes for culture. For the piped system, water was allowed to run full open for 30 seconds prior to collection. Water temperature, $\mathrm{pH}$ and dissolved solids were monitored with a Hanna Instruments HI 98129 handheld unit (Hanna Instruments, Woonsocket, RI) and dissolved oxygen measured with a Milwaukee MW600 LED Portable Dissolved Oxygen Meter (Milwaukee Instruments, Rocky Mount, NC). Local temperature and rain measurements were obtained via a data logging Davis Vantage Pro2 weather station (Davis Instruments, Vernon Hills, IL).

\subsection{Microbial source tracking}

From each collection site, $500 \mathrm{~mL}$ of water was filtered through a $47 \mathrm{~mm}$ diameter mixed cellulose filter with $0.22 \mu \mathrm{m}$ pore size (EMD Millipore Corporation, Billerica, MA) using a Nalgene filter funnel unit (Thermo Scientific, Waltham, MA). The filters were thoroughly dried and then stored at $-20^{\circ} \mathrm{C}$ until used. DNA was extracted by a phenolcholoroform procedure (Blanton et al., 2011). This was followed by treatment with hexadecyltrimethyl ammonium bromide (CTAB) to remove PCR inhibitors (Ausubel et al., 2004). The final volume of DNA was brought to $200 \mu \mathrm{L}$.

The concentration of feces-associated bacteria was measured by quantitative PCR (qPCR) using unlabeled primer sets based on the 16S rRNA gene for ruminantindicative Bacteroidales (Bernhard and Field, 2000) (Bac32F: 5'AACGCTAGCTACAGGCTT 3'; Bac708R: 5' CAATCGGAGTTCTTCGTG $3^{\prime}$ ) and human-indicative Bacteroidales (HF183F 5' ATCATGAGTTCACATGTCCG 3'; Bac708R: 5' CAATCGGAGTTCTTCGTG 3'). PCR amplification was performed in $15 \mu$ reaction mixtures composed of $0.3 \mu \mathrm{M}$ of each primer, $7.5 \mu \mathrm{L}$ FastStart Universal SYBR Green Master Mix (Roche Diagnostics Corporation, Indianapolis, IN) and $2 \mu \mathrm{L}$ DNA. The cycling program was $95{ }^{\circ} \mathrm{C}$ for 10 mins, then 40 cycles of $95{ }^{\circ} \mathrm{C}(15 \mathrm{sec}), 53^{\circ} \mathrm{C}$ (30 sec), $72{ }^{\circ} \mathrm{C}(30 \mathrm{sec})$, and a final combined annealingelongation step consisting of $95^{\circ} \mathrm{C}(15 \mathrm{sec}), 60^{\circ} \mathrm{C}(15 \mathrm{sec})$ and $72{ }^{\circ} \mathrm{C}(1 \mathrm{~min})$. Standard curves were generated during each run and consisted of an amplicon generated from either a plasmid containing the target. Standard curves were run with DNA serially diluted from $1.5 \times 10^{6}$ to $1.5 \times 10^{1}$ copies. Each assay was performed in duplicate and the results averaged.

\subsection{Stool collection}

Animal feces were collected in clean $50 \mathrm{~mL}$ conical tubes from areas not in contact with the ground or surrounding vegetation soon after being produced from cows, horses and pigs. Feces were also collected from 50 residents selected at random. For randomization, all residents were included in a database, assigned numbers and 50 were selected by a random number generator. Donors were informed about the use of their stools, and only sex and age were associated with the samples. None of the selected individuals refused to participate. The human samples were collected as discarded human waste under IRB approval from University Hospitals of Cleveland, the Oswaldo Cruz Foundation Bahia and the National Council for Ethics in Research of Brazil.

\subsection{Water samples: Coliscan}

One $\mathrm{mL}$ samples were removed from water collected at each point, mixed with Coliscan Easygel media (Micrology Laboratories, Goshen, IN), and plated. After incubation $24-48$ at $25-30{ }^{\circ} \mathrm{C}$, colonies were counted manually up to $1,000 \mathrm{CFU} / \mathrm{mL}$. E. coli was differentiated from thermotolerant coliforms by their blue or pink color, respectively.

\subsection{Antibiotic resistance screening}

For antibiotic screening of water, $10 \mathrm{~mL}$ of the collected samples were centrifuged at $5,000 \mathrm{Xg}$ for $5 \mathrm{~min}$. The pellet was re-suspended in tryptic soy broth (TSB, Becton-Dixon, Franklin Lakes, New Jersey, USA) and incubated for 24 hours at $36{ }^{\circ} \mathrm{C}$. The TSB culture was spread to form a lawn on MacConkey agar (Oxoid, Basingstoke Hampshire, UK), and antimicrobial discs for ciprofloxacin $(5 \mu \mathrm{g})$, cefotaxime $(30 \mu \mathrm{g})$ and meropenem $(10 \mu \mathrm{g})$ (Laborclin, Pinhais, Paraná, Brazil) were place on the plate for 18 to 24 hours at $36^{\circ} \mathrm{C}$. All colonies growing within the inhibition zone of a disc and with distinct morphology were isolated and identified.

\subsection{Species identification}

Genus and species of the isolates were identified by Enterokit B (Probac do Brasil, São Paulo). The kits were read after inoculation from isolated colonies and incubation for 18 to 24 hours at $36{ }^{\circ} \mathrm{C}$. For lactose non-fermenters, genus and species were identified using an NF II kit (Probac do Brasil, São Paulo) for 48 to 72 hours at $36 \pm 2{ }^{\circ} \mathrm{C}$ and subsequently read.

\subsection{Coliform antibiotic resistance confirmatory assay}

Antibiotic resistance was confirmed using the qualitative disc diffusion method (Kirby-Bauer) following standardized criteria of the Clinical Institute and Laboratory Standards (CLSI) (CLSI, 2015). Thus, after species identification, a $0.9 \%$ saline solution was inoculated with coliform isolates 
to a MacFarland standard turbidity (McFarland, 1907) of 0.5. This was spread to form a lawn on Mueller-Hinton Agar (BD, USA) and discs placed for ciprofloxacin (CIP $5 \mu \mathrm{g}$ ), ceftazidime (CAZ $30 \mu \mathrm{g}$ ), cefepime (FEP $30 \mu \mathrm{g}$ ), cefotaxime (CTX $30 \mu \mathrm{g}$ ), amoxicillin clavulanic acid (AMC $30 \mu \mathrm{g}$ ), and aztreonam (ATM $30 \mu \mathrm{g}$ ) (Laborclin, Pinhais, Paraná, Brazil). The disk diffusion method was also used for phenotypic assessment of extended spectrum betalactamase (ESBL) production (CLSI, 2015). The plates were subsequently incubated for 16 to 24 hours at $36{ }^{\circ} \mathrm{C}$ in $5 \%$ $\mathrm{CO}_{2}$. The diameters of the halos of growth inhibition around each disc were measured in millimeters and compared to the size of inhibition zones published in CLSI 2015, classifying them as sensitive, intermediate or resistant. The clinical laboratory of the Bahiana School of Medicine and Public Health where the isolations, identifications and antimicrobial susceptibility were evaluated is certified by ISO 9001: 2008 and follows all monthly quality control measures required by CLSI guidelines. Reference strain ATCC 25922 E. coli and ATCC700603 Klebsiella pneumoniae were used for quality control.

\subsection{Fecal samples}

For fecal samples, individual stools were homogenized using a clean cotton swab, which was placed in $1 \mathrm{~mL}$ of Cary-Blair medium for transport at $25-27{ }^{\circ} \mathrm{C}$ for 24 hs. Bacteria were plated using the swab tip on 2 plates of MacConkey agar, both containing CAZ $(2 \mu \mathrm{g} / \mathrm{mL})$ and one with and one without CIP $(10 \mu \mathrm{g} / \mathrm{mL})$ for 24 hours at $36{ }^{\circ} \mathrm{C} \pm 2{ }^{\circ} \mathrm{C}$. Each lactose-fermenting colony with distinct morphology on MacConkey plates was isolated and frozen in Tryptic Soy Broth with 30\% glycerol for further studies. Species identification was performed using the MALDITOF® automated method, and antimicrobial resistance profiles including ESBL phenotype were performed with VITEK@-2 (bioMérieux, Marcy l'Etoile, FRA) following the standardization criteria of the Clinical and Laboratory Standards Institute (CLSI, 2015). These studies were carried out at the Laboratory of Clinical Analysis of Hospital São Rafael, Salvador, Bahia.

\subsection{PCR identification of quinolones, cephalosporinases and carbapenamases}

Published primers for PCR were used to detect 3 common resistance genes for quinolones (qnrA, qnrS, aac6') (Guillard et al., 2010; Yu et al., 2015), for the cephalosporins CTX-M (Jemima and Verghese, 2008) (Pagani et al., 2003), and 6 common carbapenamase genes (blaKPC, blaIMP, blaVIM, blaNDM, blaSPM, blaOxa-48-like) (Doyle et al., 2012) in water filtrates and plasmids from a resistant isolate. Multiplex runs for carbapenemases produced inconsistent results for complex mixtures of DNA from the filtrates in preliminary studies. Therefore, all samples were amplified with primer pairs for individual targets.

\section{Results}

\subsection{Water quality}

Physical characteristics of the Jiquiriçá and Brejões Rivers were recorded in July 2015 and monthly over the succeeding 12 months (as show in Table 1). The flow in both rivers varies with the season, and in some years, flow entering the community is absent for the Jiquiriçá for 2-3 months characterizing it as an intermittent river. In general, $70 \%$ of the flow at the confluence is from the Brejões at $1.13 \mathrm{~m}^{3} / \mathrm{sec}$. The mean river temperature between $10 \mathrm{am}$ and $2 \mathrm{pm}$ is $22.5^{\circ} \mathrm{C}$ and is $2{ }^{\circ} \mathrm{C}$ cooler than the average ambient temperature. The highest $\mathrm{pH}$ was located at the junction of the two rivers (Point 3 ) and the lowest where the Brejões overflowed into a pasture (Point 6). While the source for piped water registered $\mathrm{pH} 7.5, \mathrm{pH}$ rose to 8.4 after the treatment station, possibly because of the chlorination process. The lowest oxygenation for the river system was also found at the Point 3 and highest at the source of drinking water (Point 12). The concentration of dissolved solids in the Brejões was 1/5th that in the Jiquiriçá. The dilution of dissolved solids in the Jiquiriça by the Brejões confirms the calculation of 4 fold higher discharge from the Brejões.

Table 1. Physico-chemical properties of water samples and coliform cultures count from evaluated points in Jenipapo-Bahia.

\begin{tabular}{|c|c|c|c|c|c|c|c|c|c|c|c|c|}
\hline & \multicolumn{5}{|c|}{ Jiquiriçá River } & \multicolumn{5}{|c|}{ Brejões River } & \multicolumn{2}{|c|}{ Tap Water } \\
\hline & 1 & 2 & 3 & 4 & 5 & 6 & 7 & 8 & 9 & 10 & 11 & 12 \\
\hline Discharge $(\mathrm{L} / \mathrm{sec})^{*}$ & - & 430.2 & $1,560.3$ & $1,435.7$ & - & - & - & - & - & - & - & - \\
\hline Temperature $\left({ }^{\circ} \mathrm{C}\right)$ & 22.8 & 23.0 & 22.6 & 22.5 & 22.6 & 23.2 & 22.6 & 22.2 & 22.1 & 22.1 & 23.1 & 23.9 \\
\hline $\mathrm{pH}$ & 7.7 & 7.9 & 8.1 & 8.0 & 7.6 & 7.5 & 7.4 & 6.6 & 7.4 & 7.9 & 8.4 & 8.3 \\
\hline Dissolved $\mathrm{O}_{2}(\mathrm{mg} / \mathrm{L})$ & 6.8 & 5.3 & 5.0 & 6.0 & 6.5 & 7.3 & 6.0 & 6.6 & 6.1 & 5.6 & 7.5 & 7.5 \\
\hline Conductivity $(\mu \mathrm{S} / \mathrm{cm})$ & 2,651 & 2,852 & 896 & 935 & 933 & 89 & 574 & 511 & 498 & 497 & 72 & 64 \\
\hline Dissolved Solids (ppm) & 1,326 & 1,426 & 563 & 468 & 466 & 32 & 287 & 254 & 245 & 246 & 35 & 32 \\
\hline $\begin{array}{l}\text { Total coliforms } \\
\text { (colonies } / \mathrm{mL} \text { ) }\end{array}$ & 172 & 148 & 224 & 284 & 296 & 224 & 136 & 220 & 232 & 242 & 148 & 136 \\
\hline E. coli $($ colonies $/ \mathrm{mL})$ & 49 & 23 & 24 & 27 & 46 & 2 & 4 & 10 & 6 & 8 & 2 & 4 \\
\hline
\end{tabular}

*The discharge was measured on the Jiquiriçá River prior (point 2) and after joining the Brejões (points 3 and 4). The Brejões River discharge rate is the difference between point 2 and the average of 3 and 4. 


\subsection{E. coli and total coliforms}

Coliforms were identified by Coliscan culture along both rivers in July 2015 (see Figure 2). The distribution of E. coli showed highest concentration at both the upstream and downstream margins of the community on the Jiquiriçá River (see Figure 2). Total coliforms were most intense near the population center of the community and downstream as the rivers passed through the remaining section of the community. The surface water concentrations of $E$. coli and total coliforms was lowest at the source of the piped water supply and were further reduced by half after water treatment, but were never zero. E. coli was present at 2-4 CFU/mL in samples of piped water (Points 11 and 12), and the concentrations of other coliforms were at 148 and $136 \mathrm{CFU} / \mathrm{mL}$, respectively. Therefore, according to Brazilian Federal Environmental Council - CONAMA standards of human drinking water (zero E. coli $\mathrm{CFU} / \mathrm{mL}$ ), the evaluated water is not appropriate for use.

\subsection{Microbial source tracking}

Human fecal contamination in both rivers showed increasing concentration as the rivers passed the more densely populated parts of the community, but the concentration was generally 3-4-fold higher in the Jiquiriçá than the Brejões (see Figure 3). This pattern differed from drier months in that peak human fecal contamination, and E. coli concentration was consistently highest at Point 8 on the Brejões from the end of 2014 through mid-2015 (not shown), and the point of maximal concentration moved downstream to point 4 after June 2015. Surface water collected from the source of Jenipapo's piped water showed the lowest concentration of both cultured E. coli and human Bacteroides. There was only weak correlation between the concentration of E. coli and human indicative Bacteroides $\left(r^{2}=0.40\right.$ following log transformation for normality). The distribution and intensity of ruminant fecal contamination by MST was similar for both rivers (see Figure 3).

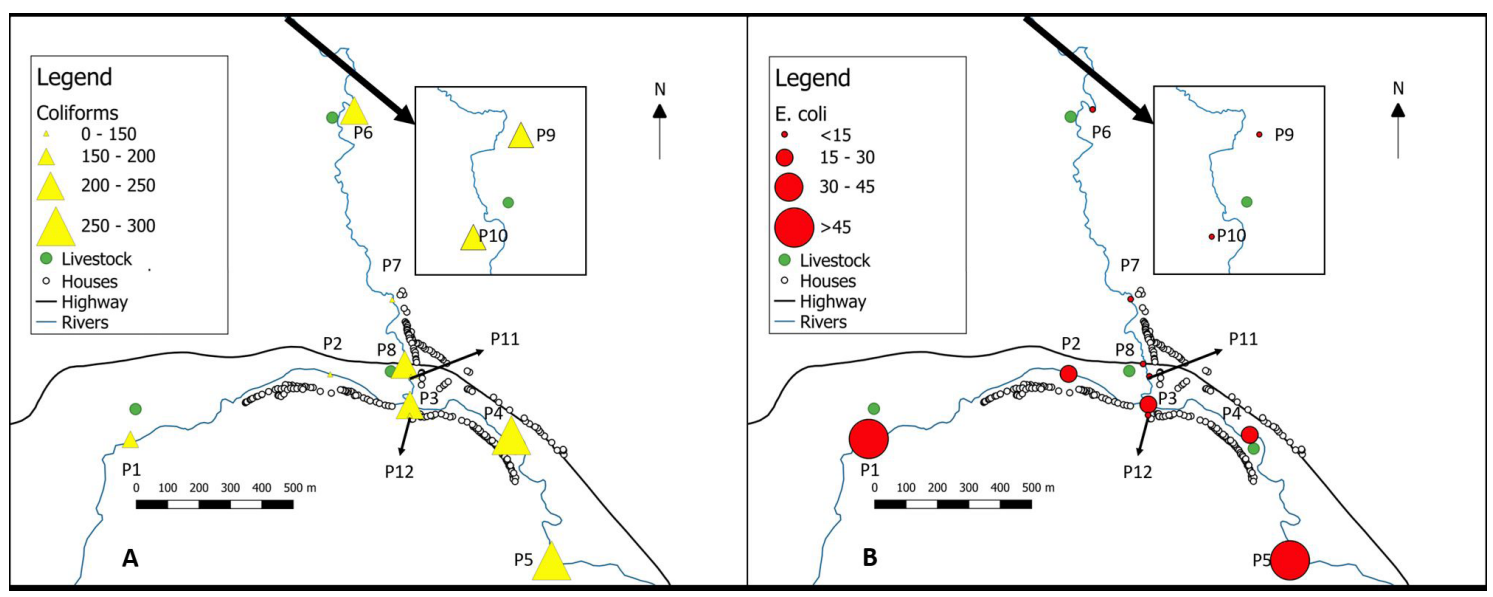

Figure 2. Locations and concentrations of coliforms and E. coli at water collection points. A volume of water ( $100 \mu \mathrm{l}-1 \mathrm{ml})$ collected mid-stream was plated using the Coliscan culture system. Colonies were identified and counted at $48 \mathrm{~h}$. The size of the indicated shapes in the figure is proportional to the number of colonies/ml cultured as indicated in the legend. Inset shows points 12 and 13 at the same scale as the main figure.

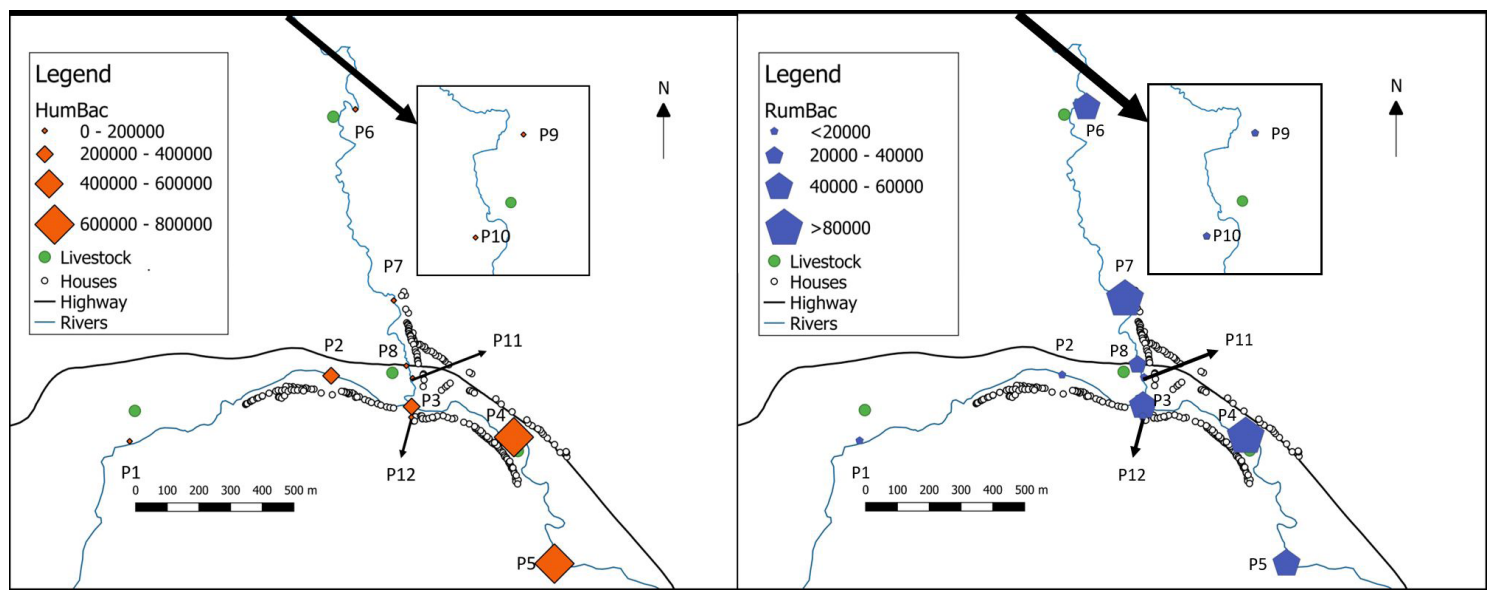

Figure 3. Locations and copy numbers for human- and ruminant-indicative Bacteroides spp. DNA extracted from the material retained from filtration of $500 \mathrm{ml}$ was used for qPCR determination of rDNA copy number. The size of the indicated shapes in the figure is proportional to the copy number $/ \mathrm{ml}$ at that point as indicated in the legend. Inset shows points 12 and 13 at the same scale as the main figure. 


\subsection{Antimicrobial resistance}

Water samples: Bacteria resistant to at least one of 3 screening antibiotics (CIP, CTX or MPM) were isolated at every water contact site sampled for a total of 32 isolates. Most resistant isolates tested (88\%) were non-lactose fermenters that belonged to genera important in healthcare associated infections: Stenotrophomonas sp., Burkholderia sp., Acinetobacter sp., and Pseudomonas sp. (as show in Table 2). However, only 4 isolates ( 3 identified as E. coli and 1 identified as Citrobacter freundii) were Enterobacteriaceae. In screening, most isolates appeared to be resistant to multiple drugs. Confirmatory Kirby-Bauer disk susceptibility testing was performed for these antibiotic resistant Enterobacteriaceae (as show in Table 3). CTX resistance was not confirmed for two E. coli isolates, CIP resistance in another. The $C$. freudii isolate was resistant to CPM, but was sensitive to carbapenems by VITEK ${ }^{\odot}-2$ system analysis at the Cleveland Veteran's Administration Hospital's microbiology laboratory.

\subsection{Fecal samples}

All bacterial isolates collected in screening of stool were resistant to $10 \mathrm{mg} / \mathrm{mL}$ of ciprofloxacin and a further set were doubly resistant to ciprofloxacin and cefotaxime (as shown in Table 4). These were differentiated on screening only as lactose positive or negative. Confirmatory identification and antibiotic resistance profile were performed only on the lactose fermenters by VITEK@ -2 .

Table 2. Bacterial identification and initial screening culture of antibiotic sensitivity of surface water samples from the Jiquiriçá and Brejões Rivers.

\begin{tabular}{|c|c|c|c|c|}
\hline $\begin{array}{l}\text { Collection } \\
\text { Points }\end{array}$ & Isolates and Idenfication* & $\begin{array}{l}\text { Number of } \\
\text { isolates }\end{array}$ & $\mathrm{CIP}^{* *}$ & CTX $^{* *}$ \\
\hline & Non-glucose fermenters & 28 & 19 & 27 \\
\hline $1,2,3,9,10$ & Stenotrophomonas maltophilia or Burkholderia spp & 6 & 2 & 6 \\
\hline 2,5 & $\begin{array}{l}\text { Achromobacter denitrificans or Delftia acidovorans or } \\
\text { Oligella urethralis }\end{array}$ & 2 & 2 & 2 \\
\hline $2,4,8,11$ & Acinetobacter spp & 7 & 6 & 7 \\
\hline $2,4,11$ & Pseudomonas spp. & 5 & 5 & 5 \\
\hline 9 & Chromobacterium violaceum & 1 & 1 & 1 \\
\hline \multirow[t]{2}{*}{$1,6,7,8,12$} & Unidentified & 7 & 3 & 6 \\
\hline & Glucose fermenters & 4 & 3 & 1 \\
\hline $1,4,5,11$ & E. coli & 4 & 3 & 1 \\
\hline
\end{tabular}

${ }^{*}$ Genus and species of glucose fermenters and non-glucose fermenters, were identified using biochemical tests by Enterokit B and NF II kit (Probac do Brasil, São Paulo), respectively; ${ }^{* *}$ Resistance (CIP: ciprofloxacin; CTX: cefotaxime).

Table 3. Confirmatory antimicrobial resistance profile of $E$. coli ESBL-producer from different sources.

\begin{tabular}{|c|c|c|c|c|c|c|c|c|c|c|}
\hline ISOLATE & SAM & TZP & CXM & FEP & CAZ & CRO & IPM & CIP & GEN & AMK \\
\hline *Water4 & $\mathrm{S}$ & $S$ & $\mathrm{R}$ & $\mathrm{R}$ & $\mathrm{R}$ & $\mathrm{R}$ & $S$ & $S$ & $S$ & S \\
\hline${ }^{* *}$ Cow2 & I & S & $\mathrm{R}$ & $\mathrm{R}$ & $\mathrm{R}$ & $\mathrm{R}$ & S & $\mathrm{R}$ & S & S \\
\hline ***Hum12 & I & S & $\mathrm{R}$ & $\mathrm{R}$ & $\mathrm{R}$ & $\mathrm{R}$ & S & $\mathrm{R}$ & S & S \\
\hline Hum13 & I & S & $\mathrm{R}$ & $\mathrm{R}$ & $\mathrm{R}$ & $\mathrm{R}$ & S & $\mathrm{R}$ & S & S \\
\hline Hum15 & $\mathrm{R}$ & S & $\mathrm{R}$ & $\mathrm{R}$ & $\mathrm{R}$ & $\mathrm{R}$ & S & $\mathrm{R}$ & S & S \\
\hline Hum18 & I & S & $\mathrm{R}$ & $\mathrm{R}$ & $\mathrm{R}$ & $\mathrm{R}$ & S & $\mathrm{R}$ & S & S \\
\hline Hum21 & I & S & $\mathrm{R}$ & $\mathrm{R}$ & $\mathrm{R}$ & $\mathrm{R}$ & S & $\mathrm{R}$ & S & S \\
\hline Hum28 & $\mathrm{R}$ & S & $\mathrm{R}$ & $\mathrm{R}$ & $\mathrm{R}$ & $\mathrm{R}$ & S & $\mathrm{R}$ & S & S \\
\hline Hum30 & I & S & $\mathrm{R}$ & $\mathrm{R}$ & $\mathrm{R}$ & $\mathrm{R}$ & S & $\mathrm{R}$ & S & S \\
\hline Hum35 & $\mathrm{R}$ & S & $\mathrm{R}$ & $\mathrm{R}$ & $\mathrm{R}$ & $\mathrm{R}$ & S & $\mathrm{R}$ & S & S \\
\hline Hum36 & $\mathrm{R}$ & S & $\mathrm{R}$ & $\mathrm{R}$ & $\mathrm{R}$ & $\mathrm{R}$ & S & $\mathrm{R}$ & S & $S$ \\
\hline Hum40 & I & S & $\mathrm{R}$ & $\mathrm{R}$ & $\mathrm{R}$ & $\mathrm{R}$ & S & $\mathrm{R}$ & S & S \\
\hline Hum50 & $\mathrm{R}$ & $\mathrm{R}$ & $\mathrm{R}$ & $\mathrm{R}$ & $\mathrm{R}$ & $\mathrm{R}$ & S & S & S & S \\
\hline
\end{tabular}

*Water samples; ${ }^{* *}$ Cow stool sample; ${ }^{* * *}$ Human stool sample. The confirmatory antimicrobial profile was performed in $E$. coli ESBL-producer collected from stool and water samples. ESBL: extended spectrum beta lactamase producer; SAM: ampicillin/sulbactam acid; TZP: piperacillin/tazobactam; CXM: cefuroxime; FEP: cefepime; CAZ: ceftazidime; CRO: ceftriaxone; IPM: imipenem; CIP: ciprofloxacin; GEN: gentamicin; AMK: amikacin. 
Table 4. Initial screening of cephalosporin and fluoroquinolone resistance profiles in all gram-negative bacteria of water and stool samples in Jenipapo-Bahia.

\begin{tabular}{lcccc}
\hline & $\begin{array}{c}\text { CIP } \mathbf{~ 1 0} \mu / \mathbf{m L} \\
\text { enterobacteria }\end{array}$ & $\begin{array}{c}\text { CIP 10 } \mu / \mathbf{m L} \\
\text { non-enterobacteria }\end{array}$ & $\begin{array}{c}\text { CTX 2 } \mu \mathbf{g} / \mathbf{m L} \\
\text { enterobacteria }\end{array}$ & $\begin{array}{c}\text { CTX 2 } \mu \mathbf{g} / \mathbf{m L} \\
\text { non-enterobacteria }\end{array}$ \\
\hline Piped water $(\mathrm{n}=2)$ & $50 \%(1)$ & $100 \%(2)$ & $0 \%(0)$ & $100 \%(2)$ \\
Rivers $(\mathrm{n}=10)$ & $30 \%(3)$ & $100 \%(10)$ & $10 \%(1)$ & $100 \%(10)$ \\
Humans $(\mathrm{n}=50)$ & $42 \%(21)$ & $10 \%(5)$ & $22 \%(11)$ & $30 \%(15)$ \\
Pigs $(\mathrm{n}=4)$ & $100 \%(4)$ & $50 \%(2)$ & 0 & $50 \%(2)$ \\
Horses $(\mathrm{n}=2)$ & 0 & 0 & 0 & 0 \\
Cow $(\mathrm{n}=7)$ & 0 & 0 & $14 \%(1)$ & $43 \%(3)$ \\
\hline
\end{tabular}

CIP: ciprofloxacin; CTX: cefotaxime, n: number of sites or individuals; 50 Humans $8.4 \%$ of the population; 4 pigs $8.8 \%$ of the population.

\subsection{PCR for environmental antibiotic resistance genes}

There was no amplification of genes from any class of antibiotic resistance tested, although all DNA amplified with human- and ruminant-indicative Bacteroides sp. primer and for positive controls.

\section{Discussion}

The confluence of two rivers in the small community of Jenipapo results in 3 segments with differing physical characteristics. These segments are the upper Jiquiriçá, the Brejões and the combined flow of both rivers. These differed mainly in the concentration of dissolved solids and the amount of flow. In a previous cross-sectional study we found that the segment downstream of the confluence of the 2 rivers and immediately downstream of the densest human habitation (Points 3 and 4 ) had the highest concentration of human and ruminant fecal contamination (Ponce-Terashima et al., 2014). This was confirmed here to be a typical pattern. Ruminant fecal contamination of the river systems in Jenipapo is evident from the run-off of fields that line the river even inside the community. Pasture represents $80 \%$ of the land usage along this river system (Fernandes et al., 2010), and MST analysis was also consistent with ruminant fecal contamination. Less obvious is the degree of human contamination, but from interviews of the whole population, at least half of the homes send their human waste directly to the river. Schistosomiasis, a condition dependent on human fecal contamination of surface waters, has been prevalent and correlates with this source of contamination (Ponce-Terashima et al., 2014). MST shows an increasing concentration of human fecal contamination from upstream, continuing through the population center of the community and falling off after the last home. This was mirrored by the total coliform count. The $E$. coli counts, by contrast did not reflect well the river flow or the known concentration of human habitation. This may reflect the multiple sources for $E$. coli and its ability to survive and multiply in the environment compared to the strains of Bacteroides used as fecal markers.

In this part of rural Bahia state, Brazil, we particularly wished to determine the prevalence of antibiotic resistant Enterobacteriaceae. The Enterobacteriaceae are the gramnegative bacteria most responsible for human disease (Cherkaoui et al., 2014) and they are just as important in nosocomial and outpatient infections in Brazil (Marra et al.,
2011). As a class, they are becoming resistant to nearly all available antibiotics. In Jenipapo, bacteria resistant to one or more antibiotics were found at all sites, but only 4 of 32 were Enterobacteriaceae; 3 were E. coli and 1 Citrobacter freundii. C. freundii is often multidrug resistant due to plasmid-encoded resistance genes, and this isolate was resistant to all agents tested, except MEM upon confirmatory testing.

Ciprofloxacin was the drug to which most of the Enterobacteriaceae were resistant, yet quinolones in particular are not commonly used by farmers and ranchers in the region (Bokma-Bakker et al., 2014) (and personal communication, Dr. Fred da Silva Julião). Government surveillance for quinolone residues indicate broad compliance in Brazil (Gouvêa et al., 2015). Together with the high prevalence of human fecal markers, this suggests that human fecal contamination was the likely source. In China (Ma et al., 2009) and Poland (Lenart-Boron et al., 2016), non-therapeutic uses of fluoroquinolones in poultry are still permitted. In these countries, a wide range of plasmids with genes responsible for fluoroquinolone resistance are prevalent in food animals and surface waters near farms. By contrast, in Jenipapo, we were unable to demonstrate the presence of any plasmid-mediated resistance genes as reservoirs in any of the waters despite both human and animal fecal contamination. This contrast may be due in part to the absence of industrial farming operations and feedlots in the area. Also, Brazil banned the addition of all but two antibiotics to feed for prophylaxis and growth promotion in 2009 and has greatly restricted the classes of antibiotic permitted in therapeutic use (Maron et al., 2013). This is not to say that the law may not be flaunted (Regitano and Leal, 2010), but these compounds are not in widespread use outside of large poultry mills in the south of the country (Bokma-Bakker et al., 2014).

In our screening cultures, most resistant gram-negative isolates did not ferment lactose, and none of these were Enterobacteriaceae. In rural areas of Brazil as well as the rest of the world, there is often close contact between bacteria of human and animal origin. Antibiotic use in animals and in humans appears to be lower in Brazil than in the US (Laxminarayan et al., 2013; Van Boeckel et al., 2015), yet antibiotic resistance is no less of a problem in Brazilian hospitals (Marra et al., 2011). One major difference between the US and Brazil is the degree of human sanitation (Bartley et al., 2019). The mixing of fecal waste from any source increases the potential for horizontal transmission 
of resistance elements among bacteria. In Jenipapo, 50\% of human waste goes directly into the rivers that serve as source of drinking water, recreation, and also used by the population to sanitize and cook food, especially fruits and vegetables. In addition, casual contact with the river is common for children crossing to go to school or adults going back and forth to access the highway. A large amount of waste from livestock also goes directly into the river, especially during periods of rain.

One of the limitations of this study is that it does not represent an unbiased survey. Colonies were selected initially on subjective criteria and there is no true denominator (total number of bacteria cultured) for the numbers of resistant isolates. The number of resistant genes assayed is a small number of some of the most important species. In particular, there are at least a dozen plasmid-encoded genes that contribute to fluoroquinolone resistance, and we tested three of these. The study is crosssectional and represents what was identified on one day in one season. Other seasons and other years might alter some conclusions.

To summarize: in July of 2015, in 10 points along the Jiquiriçá and Brejões Rivers the average of fecal contamination was $219 \mathrm{CFU} / \mathrm{mL} /$ point total coliforms and 20 E. coli $/ \mathrm{CFU} / \mathrm{mL} /$ point. Coliforms, but not E. coli were also identified in the drinking water system. Bacteria resistant to at least one major class of antibiotic were isolated from each point tested including the drinking water supply. In comparison to sites in countries with less restrictive use of antibiotics in livestock, there was less evidence of antimicrobial phenotypic and genotypic resistance in this rural area despite ample human and ruminant fecal contamination.

\section{Acknowledgements}

We wish to thank Bahiana School of Medicine and Public Health for their cooperation and use of the clinical laboratory for the microbiological analyses. We would also like to acknowledge the contribution of Adriano Pereira Coelho Santos for the map designs and Dr. Cleiton Silva Santos for his contributions on the molecular biology experiments.

Funding for this study was provided by the CNPq Special Visiting Professor Award, Process: 313752/2013-3. The funding agency did not participate or influence the study design, interpretation of the data or writing of the manuscript.

\section{References}

AGÊNCIA NACIONAL DE ÁGUAS - ANA, 2017. Atlas esgotos: despoluição de bacias hidrográficas. Brasília: ANA.

AUSUBEL, F.M., BRENT, R., KINGSTON, R.E., MOORE, D.D., SEIDMAN, J.G., SMITH, J.A. and STRUHL, K., 2004. Preface. Current Protocols in Molecular Biology, vol. 66, no. 1, pp. 1. http://dx.doi. org/10.1002/0471142727.mbprefs66.

BAKER, S., 2015. Infectious disease: a return to the pre-antimicrobial era Science, vol. 347, no. 6226, pp. 1064-1066. http://dx.doi. org/10.1126/science.aaa2868. PMid:25745145.
BARBOSA, L.M., SILVA, L.K., REIS, E.A., AZEVEDO, T.M., COSTA, J.M., BLANK, W.A., REIS, M.G. and BLANTON, R.E., 2013. Characteristics of the human host have little influence on which local Schistosoma mansoni populations are acquired. PLoS Neglected Tropical Diseases, vol. 7, no. 12, pp. e2572. http:// dx.doi.org/10.1371/journal.pntd.0002572. PMid:24340115.

BARTLEY, P.S., DOMITROVIC, T.N., MORETTO, V.T., SANTOS, C.S., PONCE-TERASHIMA, R., REIS, M.G., BARBOSA, L.M., BLANTON, R.E., BONOMO, R.A. and PEREZ, F., 2019. Antibiotic resistance in Enterobacteriaceae from surface waters in urban Brazil highlights the risks of poor sanitation. The American Journal of Tropical Medicine and Hygiene, vol. 100, no. 6, pp. 1369-1377. PMid:30994094.

BERGLUND, B., 2015. Environmental dissemination of antibiotic resistance genes and correlation to anthropogenic contamination with antibiotics. Infection Ecology \& Epidemiology, vol. 5, no. 1, pp. 28564. http://dx.doi.org/10.3402/iee.v5.28564. PMid:26356096.

BERNHARD, A.E. and FIELD, K.G., 2000. A PCR assay to discriminate human and ruminant feces on the basis of host differences in Bacteroides-Prevotella genes encoding 16S rRNA. Applied and Environmental Microbiology, vol.66, no. 10, pp. 4571-4574. http:// dx.doi.org/10.1128/AEM.66.10.4571-4574.2000. PMid:11010920.

BLANTON, R.E., BLANK, W.A., COSTA, J.M., CARMO, T.M., REIS, E.A., SILVA, L.K., BARBOSA, L.M., TEST, M.R. and REIS, M.G., 2011. Schistosoma mansoni population structure and persistence after praziquantel treatment in two villages of Bahia, Brazil. International Journal for Parasitology, vol. 41, no. 10, pp. 1093-1099. http://dx.doi.org/10.1016/j.ijpara.2011.06.002. PMid:21784077.

BOKMA-BAKKER, M., BONDT, N., NEIJENHUIS, F., MEVIUS, D.J. and RUITER, S.J.M., 2014 [viewed 17 December 2019]. Antibiotic use in Brazilian broiler and pig production: an indication and forecast of trends [online]. Wageningen: Wageningen Livestock Research. Available from: http://www.livestockresearch.wur.nl

BONELLI, R.R., MOREIRA, B.M. and PICÃO, R.C., 2014. Antimicrobial resistance among Enterobacteriaceae in South America: History, current dissemination status and associated socioeconomic factors. Drug Resistance Updates, vol. 17, no. 1-2, pp. 24-36. http://dx.doi.org/10.1016/j.drup.2014.02.001. PMid:24618111.

BROWN-JAQUE, M., CALERO-CÁCERES, W. and MUNIESA, M., 2015. Transfer of antibiotic-resistance genes via phage-related mobile elements. Plasmid, vol. 79, pp. 1-7. http://dx.doi.org/10.1016/j. plasmid.2015.01.001.

CHANG, Q., WANG, W., REGEV-YOCHAY, G., LIPSITCH, M. and HANAGE, W.P., 2015. Antibiotics in agriculture and the risk to human health: how worried should we be? Evolutionary Applications, vol. 8, no. 3, pp. 240-247. http://dx.doi.org/10.1111/ eva.12185. PMid:25861382.

CHERKAOUI, A., EMONET, S., RENZI, G., RIAT, A., GREUB, G. and SCHRENZEL, J., 2014. ESBL and carbapenemases in Enterobacteriaceae. Revue Medicale Suisse, vol. 10, no. 450, pp. 2142-2148. PMid:25549375.

CLINICAL AND LABORATORY STANDARDS INSTITUTE - CLSI, 2015 [viewed 17 December 2019]. M02-A12: performance standards for antimicrobial disk susceptibility tests approved standard [online]. 12th ed. Wayne: CLSI. Available from: www.clsi.org

DOYLE, D., PEIRANO, G., LASCOLS, C., LLOYD, T., CHURCH, D.L. and PITOUT, J.D., 2012. Laboratory detection of Enterobacteriaceae that produce carbapenemases. Journal of Clinical Microbiology, vol. 50, no. 12, pp. 3877-3880. http://dx.doi.org/10.1128/ JCM.02117-12. PMid:22993175.

FERNANDES, N.B., MOREAU, M.S., MOREAU, A.M.S.S. and COSTA, L.M., 2010. Capacidade de uso das terras na bacia hidrográfica do jiquiriçá, recôncavo sul da Bahia. Caminhos de Geografia, vol. 11, no. 34, pp. 105-122. 
GALLINI, A., DEGRIS, E., DESPLAS, M., BOURREL, R., ARCHAMBAUD, M., MONTASTRUC, J.L., LAPEYRE-MESTRE, M. and SOMMET, A. 2010. Influence of fluoroquinolone consumption in inpatients and outpatients on ciprofloxacin-resistant Escherichia coli in a university hospital. The Journal of Antimicrobial Chemotherapy, vol. 65, no. 12, pp. 2650-2657. http://dx.doi.org/10.1093/jac/ dkq351. PMid:20876240.

GOUVÊA, R., SANTOS, F.F., AQUINO, M.H.C. and PEREIRA VL DE, A., 2015. Fluoroquinolones in industrial poultry production, bacterial resistance and food residues:a review. Revista Brasileira de Ciência Avícola, vol. 17, no. 1, pp. 1-10, 29. http://dx.doi. org/10.1590/1516-635x17011-10.

GUILLARD, T., CAVALLO, J.D., CAMBAU, E., DUVAL, V., BAJOLET, O., BRASME, L., DE CHAMPS, C. and VERNET-GARNIER, V., 2010. Real-time PCR for fast detection of plasmid-mediated qnr genes in extended spectrum beta-lactamase producing Enterobacteriaceae. Pathologie Biologie, vol. 58, no. 6, pp. 430-433. http://dx.doi.org/10.1016/j.patbio.2009.03.003. PMid: 19375248 .

JEMIMA, S.A. and VERGHESE, S., 2008. Multiplex PCR for blaCTX-M \&blaSHV in the extended spectrum beta lactamase (ESBL) producing Gram-negative isolates. The Indian Journal of Medical Research, vol. 128, no. 3, pp. 313-317. PMid:19052344.

KUMARASAMY, K.K., TOLEMAN, M.A., WALSH, T.R., BAGARIA, J., BUTT, F., BALAKRISHNAN, R., CHAUDHARY, U., DOUMITH, M., GISKE, C.G., IRFAN, S., KRISHNAN, P., KUMAR, A.V., MAHARJAN, S., MUSHTAQ, S., NOORIE, T., PATERSON, D.L., PEARSON, A., PERRY, C., PIKE, R., RAO, B., RAY, U., SARMA, J.B., SHARMA, M., SHERIDAN, E., THIRUNARAYAN, M.A., TURTON, J., UPADHYAY, S. WARNER, M., WELFARE, W., LIVERMORE, D.M. and WOODFORD, N., 2010. Emergence of a new antibiotic resistance mechanism in India, Pakistan, and the UK: a molecular, biological, and epidemiological study. The Lancet. Infectious Diseases, vol. 10, no. 9, pp. 597-602. http://dx.doi.org/10.1016/S1473-3099(10)701432. PMid:20705517.

LAXMINARAYAN, R., DUSE, A., WATTAL, C., ZAIDI, A.K., WERTHEIM, H.F., SUMPRADIT, N., VLIEGHE, E., HARA, G.L., GOULD, I.M., GOOSSENS, H., GREKO, C., SO, A.D., BIGDELI, M., TOMSON, G., WOODHOUSE, W., OMBAKA, E., PERALTA, A.Q., QAMAR, F.N., MIR, F., KARIUKI, S., BHUTTA, Z.A., COATES, A., BERGSTROM, R., WRIGHT, G.D., BROWN, E.D. and CARS, O., 2013. Antibiotic resistance: the need for global solutions. The Lancet. Infectious Diseases, vol. 13, no. 12, pp. 1057-1098. http://dx.doi.org/10.1016/ S1473-3099(13)70318-9. PMid:24252483.

LENART-BORON, A., AUGUSTYNIAK, K. and BORON, P., 2016. Screening of antimicrobial resistance and molecular detection of fluoroquinolone resistance mechanisms in chicken faecesderived Escherichia coli. Veterinarni Medicina, vol. 61, no. 2, pp. 80-89. http://dx.doi.org/10.17221/8721-VETMED.

LIANG, J., MAO, G., YIN, X., MA, L., LIU, L., BAI, Y., ZHANG, T. and QU, J., 2020. Identification and quantification of bacterial genomes carrying antibiotic resistance genes and virulence factor genes for aquatic microbiological risk assessment. Water Research, vol. 168, 115160. http://dx.doi.org/10.1016/j.watres.2019.115160. PMid:31614233.

MA, J., ZENG, Z., CHEN, Z., XU, X., WANG, X., DENG, Y., LÜ, D., HUANG, L., ZHANG, Y., LIU, J. and WANG, M., 2009. High prevalence of plasmid-mediated quinolone resistance determinants qnr, aac $\left(6^{\prime}\right)$-Ib-cr, and qepA among ceftiofurresistant Enterobacteriaceae isolates from companion and food-producing animals. Antimicrobial Agents and Chemotherapy, vol.53, no. 2, pp. 519-524. http://dx.doi.org/10.1128/AAC.0088608. PMid: 18936192.

MARON, D.F., SMITH, T.J.S. and NACHMAN, K.E., 2013. Restrictions on antimicrobial use in food animal production: an international regulatory and economic survey. Globalization and Health, vol.
9, no. 1, pp. 48. http://dx.doi.org/10.1186/1744-8603-9-48. PMid:24131666.

MARRA, A.R., CAMARGO, L.F., PIGNATARI, A.C., SUKIENNIK, T., BEHAR, P.R., MEDEIROS, E.A., RIBEIRO, J., GIRÃO, E., CORREA, L., GUERRA, C., BRITES, C., PEREIRA, C.A., CARNEIRO, I., REIS, M., DE SOUZA, M.A., TRANCHESI, R., BARATA, C.U. and EDMOND, M.B., 2011. Nosocomial bloodstream infections in Brazilian hospitals: analysis of 2,563 cases from a prospective nationwide surveillance study. Journal of Clinical Microbiology, vol. 49, no. 5, pp. 1866-1871. http://dx.doi.org/10.1128/JCM.00376-11. PMid:21411591.

MCFARLAND, J., 1907. The nephelometer: an instrument for estimating the number of bacteria in suspensions used for calculating the opsonic index and for vaccines. Journal of the American Medical Association, vol. XLIX, no. 14, pp. 1176. http:// dx.doi.org/10.1001/jama.1907.25320140022001f.

MEIRELLES-PEREIRA, F., PEREIRA, A.M.S., SILVA, M.C.G., GONÇALVES, V.D., BRUM, P.R., CASTRO, A.R., PEREIRA, A.A., ESTEVES, F.A. and PEREIRA, J.A.A., 2002. Ecological aspects of the antimicrobial resistance in bacteria of importance to human infections. Brazilian Journal of Microbiology, vol. 33, no. 4. http://dx.doi. org/10.1590/S1517-83822002000400002.

NEWTON, R.J., MCLELLAN, S.L., DILA, D.K., VINEIS, J.H., MORRISON, H.G., EREN, A.M. and SOGIN, M.L., 2015. Sewage reflects the microbiomes of human populations. mBio, vol. 6, no. 2, e0257414. http://dx.doi.org/10.1128/mBio.02574-14. PMid:25714718.

PAGANI, L., DELL'AMICO, E., MIGLIAVACCA, R., D'ANDREA, M.M., GIACOBONE, E., AMICOSANTE, G., ROMERO, E. and ROSSOLINI, G.M., 2003. Multiple CTX-M-type extended-spectrum $\beta$-lactamases in nosocomial isolates of Enterobacteriaceae from a hospital in Northern Italy. Journal of Clinical Microbiology, vol. 41, no. 9, pp. 4264-4269. http://dx.doi.org/10.1128/JCM.41.9.42644269.2003. PMid:12958255.

PONCE-TERASHIMA, R., KOSKEY, A.M., REIS, M.G., MCLELLAN, S.L. and BLANTON, R.E., 2014. Sources and distribution of surface water fecal contamination and prevalence of schistosomiasis in a Brazilian village. PLoS Neglected Tropical Diseases, vol. 8, no. 10, pp. e3186. http://dx.doi.org/10.1371/journal.pntd.0003186. PMid:25275467.

REGITANO, J.B. and LEAL, R.M.P., 2010. Performance and environmental impact of antibiotics in animal production in Brazil. Revista Brasileira de Ciência do Solo, vol. 34, no. 3, pp. 601-616. http://dx.doi.org/10.1590/S0100-06832010000300002.

VAIDYA, V.K., 2011. Horizontal transfer of antimicrobial resistance by extended-spectrum $\beta$ lactamase-producing enterobacteriaceae. Journal of Laboratory Physicians, vol. 3, no. 1, pp. 37-42. http:// dx.doi.org/10.4103/0974-2727.78563. PMid:21701662.

VAN BOECKEL, T.P., BROWER, C., GILBERT, M., GRENFELL, B.T., LEVIN, S.A., ROBINSON, T.P., TEILLANT, A. and LAXMINARAYAN, R., 2015. Global trends in antimicrobial use in food animals. Proceedings of the National Academy of Sciences of the United States of America, vol. 112, no. 18, pp. 5649-5654. http://dx.doi. org/10.1073/pnas.1503141112. PMid:25792457.

WIKIMEDIA COMMONS, 2011. [viewed 17 December 2019]. Bahia in Brazil.svg [online]. Available from: https://commons.wikimedia. org/wiki/File:Bahia_in_Brazil.svg.

YU, T., JIANG, X., FU, K., LIU, B., XU, D., JI, S. and ZHOU, L., 2015. Detection of extended-spectrum $\beta$-lactamase and plasmidmediated quinolone resistance determinants in Escherichia coli isolates from retail meat in China. Journal of Food Science, vol. 80, no. 5, pp. M1039-M1043. http://dx.doi.org/10.1111/17503841.12870. PMid:25864449. 